\title{
DASAR PERTIMBANGAN HAKIM TERHADAP TINDAK PIDANA KORUPSI YANG DILAKUKAN OLEH PEGAWAI NEGERI SIPIL (PNS): STUDI KASUS PUTUSAN PENGADILAN NEGERI MEDAN NOMOR: 73/PID.SUS-TPK/2018/PN.MDN
}

\author{
Naomi Sari Kristiani Harefa ${ }^{1}$, Gabriel Kevin Manik ${ }^{1}$, \\ Indra Kevin Yonathan Marpaung ${ }^{1}$, Sonya Airini Batubara ${ }^{2}$ \\ ${ }^{1}$ Mahasiswa Fakultas Hukum, Universitas Prima Indonesia, Medan \\ ${ }^{2}$ Dosen Fakultas Hukum, Universitas Prima Indonesia, Medan \\ *Penulis Korespondensi: Naomi Sari Kristiani Harefa \\ Email Korespondensi: naomiharefa@gmail.com
}

\begin{abstract}
Abstrak. Penelitian ini bertujuan untuk mengetahui pertimbangan Hakim dalam menjatuhkan putusan terhadap pegawai negeri sipil yang melakukan tindak pidana korupsi, serta untuk mengetahui penerapan kebijakan hukum terhadap pegawai negeri sipil yang melakukan tindak pidana korupsi. Penelitian ini menggunakan metode penelitian hukum normatif, yaitu suatu prosedur penelitian ilmiah untuk menemukan kebenaran berdasarkan logika keilmuan hukum, melalui sisi normatifnya. Pendekatan yang digunakan dalam penelitian ini adalah pendekatan kasus. Data yang digunakan dalam penelitian ini adalah data primer dan data sekunder. Data primer dalam penelitian ini berupa Putusan Pengadilan Negeri Medan Nomor: 73/Pid.Sus-TPK/2018/PN.Mdn. Sedangkan data sekunder diperoleh melalui berbagai referensi, yaitu peraturan perundang-undangan, serta bahan-bahan kepustakaan yang berkaitan dengan permasalahan penelitian dan juga memiliki koherensi dengan data primer. Teknik pengumpulan data yang digunakan dalam penelitian ini adalah; studi kepustakaan (library research), dan studi dokumen (document research). Adapun teknik analisis data yang digunakan adalah teknik analisis data kualitatif. Hasil penelitian menunjukkan bahwa pertimbangan Hakim didasari oleh ketentuan peraturan perundang-undangan. Melalui putusan yang dijatuhkan, Majelis Hakim berusaha mewujudkan negara yang bebas dan bersih dari korupsi, kolusi, dan nepotisme. Adapun penerapan kebijakan hukum terhadap pegawai negeri sipil yang melakukan tindak pidana korupsi oleh Majelis Hakim ialah tidak membedakan status sosial, meskipun terdakwa adalah seorang pegawai negeri sipil. Kebijakan hukum tersebut sesuai dengan pasal pelanggaran yang dikenai kepada terdakwa.
\end{abstract}

artikel dengan akses terbuka dibawah lisensi CC BY -4.0

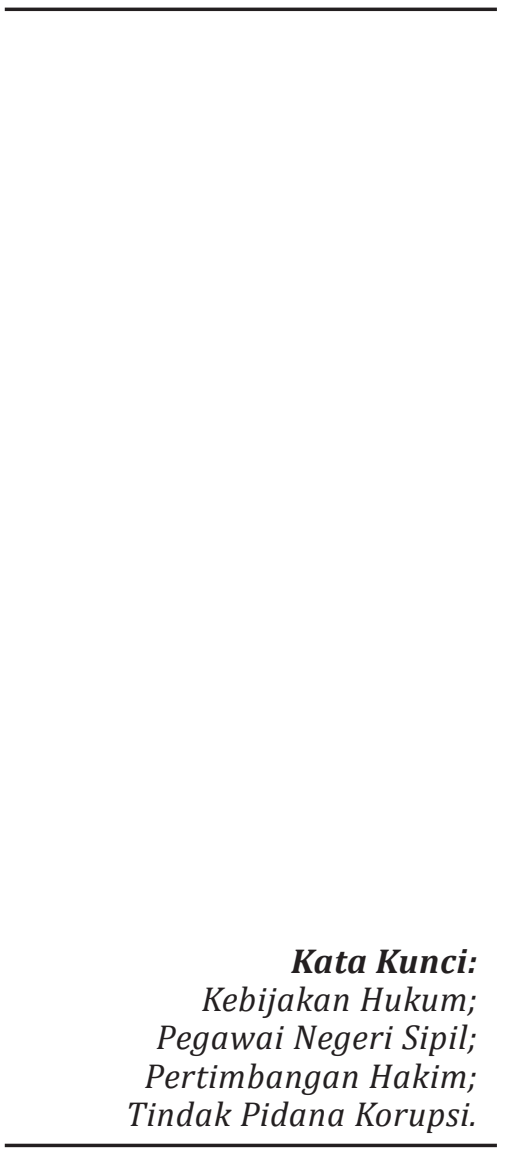




\section{PENDAHULUAN}

Korupsi selalu mendapatkan perhatian lebih jika dibandingkan dengan tindak pidana lainnya, baik di seluruh dunia maupun di Indonesia. Perhatian lebih tersebut terjadi karena dampak negatif yang ditimbulkan olehnya yang dapat menyentuh berbagai bidang kehidupan. Korupsi merupakan masalah serius yang dapat membahayakan stabilitas dan keamanan masyarakat, membahayakan pembangunan sosial, ekonomi, politik, serta dapat merusak nilai-nilai demokratis dan moralitas. Lambat laun, perbuatan tersebut seakan menjadi budaya. ${ }^{1}$

Korupsi telah menjadi ancaman nyata bagi kelangsungan negara. Sejak lama tindakan korupsi menjadi salah satu perusak tatanan negara dari dalam. Dengan kondisinya yang telah berlangsung lama tersebut, alih-alih hilang ataupun berkurang, justru akhir-akhir ini korupsi semakin marak terjadi. Bahkan publik sempat dikagetkan dengan mencuatnya pemberitaan terkait beberapa oknum yang berkiprah di bidang eksekutif, legeslatif dan yudikatif, justru dituding melakukan penyalahgunaan wewenang, penggelapan, pemerasan dalam jabatan serta menerima suap. ${ }^{2}$

Pada tahun 2012-2016, berdasarkan hasil penelitian Indonesia Corruption Watch (ICW) pelaku tindak pidana korupsi yang berlatar belakang pegawai negeri sipil (PNS), menduduki urutan atas. Sehubungan dengan data tersebut, Komisi Pemberantasan Korupsi (KPK) mencatat adanya 244 kasus tindak pidana korupsi pada tahun 2010 hingga 2016. Hal yang memprihatinkan dari data yang diungkap KPK adalah justru pelaku tindak pidana korupsi masih didominasi oleh Pegawai Negeri Sipil. ${ }^{3}$ Lebih lanjut, Data Kantor Staf Kepresidenan 2017 menyebutkan bahwa dari 1.441 kasus korupsi atau 44 \% terpidana kasus korupsi berasal dari PNS. ${ }^{4}$ Bahkan pada bulan September Tahun 2018, telah diterbitkan Surat Edaran Menteri Dalam Negeri Republik Indonesia Nomor 180/6867/SJ Tahun 2018 tentang Penegakan Hukum terhadap Aparatur Sipil Negara yang Melakukan Tindak Pidana Korupsi. Keluarnya kebijakan tersebut terkait dengan banyaknya Pegawai Negeri Sipil (PNS) yang terbukti melakukan tindak pidana korupsi dan sudah memiliki kekuatan hukum tetap (inkracht), dimana Menteri Dalam Negeri (Mendagri) Tjahjo Kumolo meminta agar mereka segera diberhentikan dengan tidak hormat. ${ }^{5}$ Apabila dilihat dari tipologi tindak pidana korupsi yang dilakukan oleh Pegawai Negeri Sipil (PNS), tindak pidana tersebut sebagian besar termasuk dalam korupsi kerugian keuangan negara. ${ }^{6}$

${ }^{1}$ Danu Surya Putra \& Rehnalemken Ginting. (2018). Analisis Dasar Pertimbangan Hakim dalam Menjatuhkan Putusan Bebas Tindak Pidana Korupsi Dana Tunjangan Penghasilan Aparat Pemerintah Desa Kabupaten Tapanuli Selatan. Recidive: Jurnal Hukum Pidana dan Penanggulangan Kejahatan, Universitas Sebelas Maret, 7(2), hlm. 126.

${ }^{2}$ Muhammad Rezza Kurniawan \& Pujiyono Pujiyono. (2018). Modus Operandi Korupsi Pengadaan Barang dan Jasa Pemerintah oleh PNS. Law Reform, Universitas Diponegoro, 14(1), hlm. 116.

${ }^{3}$ Ibid., hlm 118.

${ }^{4}$ Reni Susanti. (2020, 29 Juli). 44 Persen Terpidana Kasus Korupsi Berasal dari PNS. Dalam Kompas.com. Diakses pada tanggal 3 Agustus 2020.

${ }^{5}$ Nurmalita Ayuningtyas Harahap. (2018). Revitalisasi Manajemen Aparatur Sipil Negara Melalui Pemberhentian Tidak dengan Hormat bagi Pegawai Negeri Sipil yang Terlibat Tindak Pidana Korupsi. Jurnal Panorama Hukum, Universitas Kanjuruhan Malang, 3(2), hlm. 156.

${ }^{6}$ Ibid., 160. 
Setiap tindakan dan perbuatan hukum masyarakat telah diatur dalam undang-undang yang memiliki bidang dan cakupan masing-masing, demi ketertiban dan keadilan sosial. Salah satu bidang hukum tersebut adalah hukum pidana yang mengatur tentang ketentuan dan/atau larangan atas pelanggaran-pelanggaran dan kejahatankejahatan terhadap kepentingan umum, dimana setiap perbuatan tersebut diancam dengan sanksi yang dapat berbentuk suatu penderitaan, nestapa ataupun siksaan. ${ }^{7}$ Selanjutnya, berdasarkan poin (a) pada bagian menimbang Undang-Undang Nomor 20 Tahun 2001 tentang Perubahan atas Undang-Undang Nomor 31 Tahun 1999 tentang Pemberantasan Tindak Pidana Korupsi (selanjutnya disebut UU No. 20 Tahun 2001) menjelaskan bahwa:

"Bahwa tindak pidana korupsi yang selama ini terjadi secara meluas, tidak hanya merugikan keuangan negara, tetapi juga telah merupakan pelanggaran terhadap hak-hak sosial dan ekonomi masyarakat secara luas, sehingga tindak pidana korupsi perlu digolongkan sebagai kejahatan yang pemberantasannya harus dilakukan secara luar biasa."

Lebih lanjut, mengenai penjelasan atas tindak pidana korupsi, dalam Pasal 2 UU No. 20 Tahun 2001 mengatur bahwa:

"Setiap orang yang secara melawan hukum melakukan perbuatan memperkaya diri sendiri atau orang lain atau suatu korporasi yang dapat merugikan keuangan negara atau perekonomian negara ..."

Dalam kaitan dengan penjelasan tersebut, korupsi terjadi karena tindakan yang menyalahgunakan kewenangan atau kekuasan yang bukan untuk kepentingan bersama atau negara, melainkan kepentingan diri sendiri atau kelompok tertentu. ${ }^{8}$ Korupsi menjadi suatu tindakan yang digolongkan sebagai kejahatan luar biasa (ekstra ordinary crime). Hal tersebut tidak saja karena modus maupun teknik sistematis yang digunakan, melainkan juga akibat yang ditimbulkannya bersifat pararel dan merusak seluruh sistem kehidupan, baik dalam segi ekonomi, politik, sosial-budaya dan bahkan sampai pada kerusakan moral serta mental masyarakat. ${ }^{9}$

Dalam kehidupan sehari-hari, manusia sering dihadapkan kepada suatu kebutuhan yang mendesak, kebutuhan pemuas diri, bahkan kadang-kadang karena keinginan atau desakan untuk mempertahankan status sosial. Secara teoritik, korupsi terjadi karena dua persoalan, yakni karena ada kebutuhan (corruption by need), dan karena sikap rakus untuk menumpuk kekayaan (corruption by greed). ${ }^{10}$ Jika hanya persoalan

\footnotetext{
${ }^{7}$ Mokhammad Najih \& Soimin Soimin. (2012). Pengantar Hukum Indonesia: Sejarah, Konsep Tata Hukum, dan Politik Hukum Indonesia. Malang: Setara Press, hlm. 150.

${ }^{8}$ Listiyono Santoso, Dewi Meyriswati, \& Ilham Nur Alfian. (2014). Korupsi dan Mentalitas: Kendala Kultural dalam Pemberantasan Korupsi di Indonesia. Masyarakat, Kebudayaan dan Politik, Universitas Airlangga, 27(4), hlm. 173.

${ }^{9}$ Indra Kumalasari Munthe. (2018). Analisis Yuridis Tindak Pidana Korupsi yang Dilakukan oleh Aparatur Sipil Negara Ditinjau dalam UU Nomor 5 Tahun 2014 tentang Aparatur Sipil Negara. Jurnal Hukum Kaidah: Media Komunikasi dan Informasi Hukum dan Masyarakat, Universitas Islam Sumatera Utara, 17(2), hlm. 17.

${ }^{10}$ Budi Setiyono. (2017). Memahami Korupsi di Daerah Pasca Desentralisasi:Belajar dari Empat Studi Kasus. Politika: Jurnal Ilmu Politik, Universitas Diponegoro, 8(1), hlm. 30.
} 
kebutuhan, maka secara rasional, setiap orang yang telah terpenuhi kebutuhannya (seperti pegawai yang telah memiliki gaji tetap), tidak akan melakukan korupsi. Akan tetapi, sebagaimana uraian penjelasan di atas, menjadi ironislah keadaannya jika pegawai negeri sendiri yang melakukan tindak pidana korupsi.

Tindak pidana korupsi yang dilakukan oleh pegawai negeri sipil, mesti dilakukan penindakan sesuai hukum, dimana dalam salah satu prosesnya adalah proses persidangan di pengadilan. Peran Hakim dalam proses tersebut sangat vital, karena hakimlah yang akan memberikan putusan atas kasus tindak pidana. Putusan Hakim kemudian akan menjadi dasar dalam proses hukum selanjutnya. Oleh karena itu, putusan Hakim secara luas merupakan penentu atas keadilan, dan juga sebagai salah satu langkah untuk meminimalisir tindak pidana korupsi, khususnya yang dilakukan oleh Pegawai Negeri Sipil (PNS).

Meskipun demikian, putusan tidak hanya dapat dilihat sebagai produk, melainkan di dalamnya juga terdapat proses. Proses untuk sampai pada ketetapan putusan, jelas melalui berbagai pertimbangan tertentu. Maka upaya lebih lanjut untuk memahami bagaimana pertimbangan Hakim dalam membuat putusan terhadap tindak pidana korupsi dalam kaitan tersebut juga tidak kalah penting.

Berdasarkan latar belakang di atas, tujuan penelitian ini adalah untuk mengetahui pertimbangan Hakim dalam menjatuhkan putusan terhadap pegawai negeri sipil yang melakukan tindak pidana korupsi, serta untuk mengetahui penerapan kebijakan hukum terhadap pegawai negeri sipil yang melakukan tindak pidana korupsi. Adapun manfaat dari penelitian tersebut ialah sebagai bagian dari proses sosialisasi untuk memberikan penyadaran hukum, ${ }^{11}$ khususnya bagi Pegawai Negeri Sipil tentang ancaman, sanksi serta dampak dari tindak pidana korupsi.

\section{METODE}

Penelitian ini menggunakan metode penelitian hukum normatif, yaitu suatu prosedur penelitian ilmiah untuk menemukan kebenaran berdasarkan logika keilmuan hukum melalui sisi normatifnya. ${ }^{12}$ Dalam penelitian hukum, jenis penelitian tersebut dilakukan untuk menghasilkan argumentasi, teori atau konsep baru sebagai preskripsi dalam menyelesaikan masalah yang dihadapi. ${ }^{13}$ Pendekatan yang digunakan dalam penelitian ini adalah pendekatan kasus. Pendekatan kasus dilakukan dengan cara melakukan telaah terhadap kasus-kasus yang berkaitan dengan isu yang dihadapi dan telah menjadi putusan pengadilan yang telah mempunyai kekuatan hukum tetap. Fokus kajian di dalam pendekatan kasus adalah ratio decidendi atau reasoning,

${ }^{11}$ Salle Salle, La Ode Husen, \& Lauddin Marsuni. (2020). Tinjauan Hukum Mahkamah Konstitusi dalam Perkara Pengujian Undang-Undang Nomor 17 Tahun 2012 tentang Perkoperasian. Sovereign: Jurnal Ilmiah Hukum, CV. Social Politic Genius (SIGn), 2(2), hlm. 3.

${ }^{12}$ Sarah Sarmila Begem, Nurul Qamar, \& Hamza Baharuddin. (2019). Sistem Hukum Penyelesaian Pelanggaran Hak Asasi Manusia (HAM) Berat Melalui Mahkamah Pidana Internasional. SIGn Jurnal Hukum, CV. Social Politic Genius (SIGn), 1(1), hlm. 3.

${ }^{13}$ Peter Mahmud Marzuki. (2013). Penelitian Hukum. Jakarta: Kencana Prenada Media Group, hlm. 56. 
yaitu pertimbangan pengadilan sampai pada putusan. ${ }^{14}$ Jenis dan sumber data yang digunakan dalam penelitian ini adalah sebagai berikut:

1. Data primer yaitu data yang diperoleh seorang peneliti secara langsung dari sumbernya tanpa perantara pihak lain (langsung dari objeknya) ${ }_{1}^{15}$ dalam penelitian ini berupa Putusan Pengadilan Negeri Medan Nomor 73/Pid.Sus-TPK/2018/PN.Mdn tentang Putusan Akhir Perkara Tindak Pidana Korupsi Atas Nama Juliansyah (selanjutnya disebut Putusan PN Medan No. 73/Pid.Sus-TPK/2018/PN.Mdn);

2. Data sekunder, yaitu data yang diperoleh seorang peneliti secara tidak langsung dari sumbernya (objek penelitian), tetapi melalui sumber lain, ${ }^{16}$ dalam penelitian ini berupa bahan-bahan kepustakaan yang berkaitan dengan permasalahan penelitian dan juga memiliki koherensi dengan data primer.

Adapun pengumpulan data dalam penelitian ini menggunakan teknik dan instrumen sebagai berikut:

1. Studi dokumen (document research), yaitu pengumpulan data untuk memperoleh data primer, dimana dalam penelitian ini ialah dengan mengkaji Putusan PN Medan No. 73/Pid.Sus-TPK/2018/PN.Mdn.

2. Studi kepustakaan (library research), yaitu pengumpulan data untuk memperoleh data sekunder, dimana dalam penelitian ini berupa bahan pustaka seperti buku, kamus, jurnal, peraturan perundang-undangan dalam bentuk hard copy maupun soft copy.

Data yang telah dikumpulkan kemudian dianalisis menggunakan teknik analisis data kualitatif, yakni analisis yang berfokus pada penunjukkan makna, deskripsi, penjernihan, dan penempatan data pada konteksnya masing-masing, serta melukiskannya dalam kata-kata daripada di dalam angka-angka demi mencapai tujuan penelitian yang telah ditetapkan sebelumnya. ${ }^{17}$

\section{HASIL DAN PEMBAHASAN}

\section{A. Pertimbangan Hakim dalam Menjatuhkan Putusan terhadap Tindak Pidana Korupsi oleh Pegawai Negeri Sipil berdasarkan Putusan PN Medan No. 73/ Pid.Sus-TPK/2018/PN.Mdn}

Hakim diberi wewenang oleh undang-undang untuk menerima, memeriksa, dan memutus suatu perkara pidana. Dengan kewenangan tersebut, maka Hakim harus berbuat adil dalam menangani suatu perkara. ${ }^{18}$ Dalam memutuskan suatu perkara

\footnotetext{
${ }^{14}$ Ibid., hlm. 134.

${ }^{15}$ Suteki Suteki \& Galang Taufani. (2018). Metodologi Penelitian Hukum: Filsafat, Teori, dan Praktik. Jakarta: PT. Raja Grafindo Persada, hlm. 148.

${ }^{16}$ Ibid.

${ }^{17}$ Sanafiah Faisal. (1995). Format-Format Penelitian Sosial: Dasar-Dasar dan Aplikasi. Jakarta: PT. Raja Grafindo Persada, hlm. 256.

${ }^{18}$ Sulardi Sulardi \& Yohana Puspitasari Wardoyo. (2015). Kepastian Hukum, Kemanfaatan, dan Keadilan terhadap Perkara Pidana Anak: Kajian Putusan Nomor 201/Pid.Sus/2014/PN.Blt. Jurnal Yudisial, Komisi Yudisial Republik Indonesia, 8(3), hlm. 253.
} 
atau membuat putusan, aspek yang sangat peting bagi Majelis Hakim adalah fakta dan peristiwa yang sebenarnya. Melalui fakta dan peristiwa tersebut Majelis Hakim dapat menemukan hukum yang tepat. Majelis Hakim harus mampu menganalisis suatu peristiwa melalui pembuktian yang dilakukan di persidangan. Majelis Hakim harus melakukan penemuan hukum (rechsvinding) yang berhubungan dengan fakta dan peristiwa tersebut.

Lebih lanjut, penemuan hukum harus sejalan dengan pembuktian yang dilakukan di persidangan, karena hal tersebut adalah kegiatan yang berkesinambungan. Penemuan hukum berkaitan dengan penentuan Undang-Undang apa yang sesuai dengan peristiwa tertentu. Oleh karena itulah Undang-Undang yang digunakan oleh Majelis Hakim harus disesuaikan dengan fakta dan peristiwa yang terjadi. Setelah tahap pembuktian selesai, barulah Majelis Hakim akan menentukan atau memutuskan melalui putusan pengadilan. Hakim dalam memutuskan suatu perkara harus memperhatikan tiga faktor, yaitu keadilan, kepastian hukum dan kemanfaatan.

a. Keadilan (gerectigheit) dalam arti memberikan persamaan hak dan kewajiban semua orang tanpa terkecuali di hadapan hukum. Keadilan juga dianggap sebagai jalan keluar yang memberikan stabilitas yaitu ketertiban bagi masyarakat.

b. Kepastian Hukum (rechmatigheid) dalam arti hukum harus dijalankan secara tepat dan pasti untuk mewujudkan ketertiban masyarakat. Dengan adanya kepastian hukum maka masyarakat akan lebih menaati peraturan perundangundangan dan tidak merasa dirugikan atas pelanggaran yang dilakukan oleh orang lain. Dalam kaitan nya dengan penyelenggaraan negara yang baik bahwa hukum harus dijalankan dengan baik sehingga tidak menimbulkan kerugian bagi siapapun. Hukum harus dapat melindungi, mengayomi dan memberikan rasa aman kepada masyarakat sehingga terwujud keadilan sosial bagi masyarakat.

c. Kemanfaatan (zwechmatigheid) dalam arti hukum yang diterapkan dalam masyarakat harus mempunyai manfaat dan kegunaan yang baik bagi semua masyarakat baik yang dikenai hukuman maupun tidak. Hukum juga dapat menimbulkan keresahan dalam masyarakat apabila tidak memberikan manfaat atau kegunaan yang baik dalam masyarakat.

Sehubungan dengan penjelasan di atas, Hakim harus mempertimbangkan banyak hal dalam menjatuhkan putusan, karena nantinya putusan tersebut akan menjadi sorotan masyarakat atau bahkan akan menimbulkan polemik di masyarakat, khususnya jika ada pihak yang merasa atau menilai bahwa putusan yang dijatuhkan Hakim kurang adil. Dalam menjatuhkan putusan, sebagian besar Hakim di Indonesia menggunakan jenis pertimbangan yang sifatnya yuridis dan nonyuridis. Pertimbangan Majelis Hakim yang bersifat yuridis ialah pertimbangan 
yang didasarkan pada faktor-faktor yang terungkap di dalam persidangan dan oleh undang-undang telah ditetapkan sebagai hal yang harus dimuat di dalam putusan. Hal tersebut diantaranya yaitu dakwaan jaksa penuntut umum, keterangan saksi, keterangan terdakwa, barang-barang bukti serta pasal-pasal dalam UndangUndang yang berkaitan. Sedangkan pertimbangan Hakim yang bersifat non yuridis ialah pertimbangan yang didasarkan pada faktor-faktor lain yang tidak atau belum ditetapkan oleh peraturan perundang-undangan. Hal tersebut dapat berupa pertimbangan yang sifatnya sosiologis maupun fakta-fakta lain yang terungkap selama persidangan. ${ }^{19}$

Dalam perkara tindak pidana korupsi, dengan berdasarkan Putusan PN Medan No. 73/Pid.Sus-TPK/2018/PN.Mdn, Hakim memiliki beberapa pertimbangan, antara lain:

1. Berdasarkan alat bukti dan barang bukti yang diajukan di persidangan sehingga diperoleh fakta-fakta hukumnya. Dalam Pasal 183 KUHAP dikatakan bahwa Hakim tidak boleh menjatuhkan Pidana kepada seseorang kecuali apabila dengan sekurang-kurangnya ada dua alat bukti yang sah, ia memperoleh keyakinan bahwa suatu tindak pidana telah terjadi dan bahwa terdakwalah yang bersalah melakukannya. Selanjutnya dalam pasal 184 KUHAP dijelaskan bahwa alat bukti yang sah adalah keterangan saksi, keterangan ahli, surat, petunjuk dan keterangan terdakwa. Dalam kasus ini barang bukti berupa surat-surat ukur dan surat pengurusan izin sertifikat serta uang tunai sejumlah Rp. 8.000.000 dan Rp. 6.000.000 menjadi alat bukti yang sah dalam pembuktian yang ada pada saat terjadinya penangkapan. Selanjutnya dapat kita lihat dari keterangan saksi yang jelas dan sebagian besar memberatkan dan membenarkan bahwa Juliansyah benar melakukan tindak pidana korupsi. Dari dua alat bukti yang diajukan ke persidangan maka Juliansyah terbukti secara sah dan bersalah melakukan tindak pidana korupsi.

2. Berdasarkan fakta-fakta hukum tersebut terdakwa dapat dinyatakan telah melakukan tindak pidana yang didakwakan kepadanya. Dalam analisa putusan ini ditemukan pelanggaran yang dilakukan oleh Juliansyah dengan meminta biaya pengurusan surat-surat kepada pemilik kapal sebesar Rp.14.000.000 padahal yang seharusnya dibayarkan oleh pemilik kapal sesuai dengan peraturan perundang-undangan Penerimaan Negara Bukan Pajak (PNBP) untuk pengurusan surat ukur kapal, pas besar sementara, dan sertifikat kelaikan dan pengawakan kapal penangkap ikan adalah sebesar Rp. 325.000. Dapat kita lihat fakta hukum yang ada di sini adalah Juliansyah meminta lebih dari jumlah yang seharusnya disetorkan kepada negara. Fakta hukum selanjutnya adalah Juliansyah adalah seorang pegawai negeri sipil yang menjadi penyelenggara negara.

3. Berdasarkan seluruh unsur-unsur dari tindak pidana yang didakwakan kepadanya. Jaksa penuntut umum dalam hal ini menjadi penuntut pertama yang

${ }^{19}$ Danu Surya Putra \& Rehnalemken Ginting. (2018). Op. Cit., hlm. 127-128. 
memberikan dakwaan kepada Juliansyah dengan mengeluarkan surat dakwaan yang menjadi acuan pertama dalam acara persidangan selanjutnya di Pengadilan.

4. Berdasarkan dakwaan oleh Penuntut Umum dengan dakwaan alternatif di mana berdasarkan pembuktian dan fakta hukum di persidangan, Majelis meyakini bahwa atas perbuatan Terdakwa lebih tepat untuk diterapkan ketentuan dalam Pasal 11 Undang-Undang Nomor 20 Tahun 2001 Tentang Perubahan atas Undang-Undang Nomor 31 Tahun 1999 Tentang Pemberantasan Tindak Pidana Korupsi Jo Pasal 55 ayat (1) ke-1 KUHPidana. Dapat kita lihat bahwa jelas dalam Undang- Undang apabila pegawai negeri atau penyelenggara negara menerima hadiah atau janji yang diketahui berkaitan dengan kekuasaan atau jabatan nya atau mereka yang melakukan, menyuruh melakukan tindak pidana korupsi dapat dijatuhi sanksi pidana.

5. Berdasarkan yang dimaksud dengan 'setiap orang' sebagaimana ditentukan dalam Pasal 1 angka 3 Undang-undang Nomor 31 Tahun 1999 adalah orang perorangan (natuurlijk personen) atau termasuk korporasi (rechts personen) dan yang dimaksud dengan korporasi adalah kumpulan orang dan atau kekayaan yang terorganisasi baik merupakan badan hukum maupun bukan badan hukum yang terbukti secara sah melakukan tindak pidana korupsi.

6. Berdasarkan fakta hukum yang diperoleh di persidangan, terungkap Terdakwa Juliansyah bekerja sebagai Pegawai Negeri Sipil pada Kantor Kesyahbandaran dan Otoritas Pelabuhan Tanjungbalai Asahan di Jalan Pelabuhan Teluk Nibung Kota Tanjungbalai yang menjabat sebagai Kepala Wilayah Kerja Bagan Asahan/Pelaksana Harian KSOP Tanjung Balai Asahan sejak tahun 2016 s/d tahun 2018 sesuai dengan Surat Perintah Kepala Kantor Kesyahbandaran dan Otoritas Pelabuhan Tanjung Balai Asahan Kementerian Perhubungan Direktorat Jenderal Perhubungan Laut Nomor : KP.104/4/3/KSOP.Tba-18; bahwa terhadap unsur pegawai negeri atau penyelenggara negara telah terpenuhi oleh perbuatan Juliansyah menerima hadiah atau janji.

7. Berdasarkan yang dimaksud dengan 'Hadiah' menurut Putusan Hoge Raad tanggal 25 April 1916 adalah segala sesuatu yang mempunyai nilai dalam hal ini adalah sejumlah uang sebesar Rp. 14.000.000.

8. Berdasarkan fakta-fakta hukum tersebut di atas bahwa Juliansyah terbukti telah menerima uang dari Koko Suwendi sejumlah Rp.8.000.000,00 (delapan juta rupiah) padahal biaya PNBP terkait dengan penerbitan surat-surat kedua kapal tersebut sejumlah Rp.325.000,00 (tiga ratus dua puluh lima ribu rupiah) sejumlah Rp.6.000.000,00 (enam juta rupiah) pada hal biaya untuk penerbitan Grosse Akta kedua kapal tersebut sejumlah Rp.500.000,00 (lima ratus ribu rupiah).

9. Berdasarkan fakta-fakta hukum tersebut maka menurut penulis pengurusan surat-surat kapal tersebut patut menduga karena kekuasaan atau kewenangan yang berhubungan dengan jabatan dari Juliansyah atau yang menurut pikiran pemilik kapal ada hubungan dengan jabatan Terdakwa, oleh karena itu unsur 
ini juga telah terpenuhi di dalam perbuatan Juliansyah yaitu unsur 'Mereka yang melakukan, menyuruh melakukan atau turut melakukan perbuatan'.

10. Berdasarkan ketentuan Pasal 55 ayat (1) ke-1 KUHP, sering disebut dengan istilah deelneming, disebutkan bahwa dipidana sebagai pelaku (dader) adalah mereka yang melakukan sendiri suatu tindak pidana (plegen), mereka yang menyuruh orang lain melakukan suatu tindak pidana (doen plegen), mereka yang turut serta (bersama-sama) melakukan tindak pidana (mede plegen), dan mereka yang dengan sengaja mengajurkan orang lain melakukan tindak pidana (uitlokker).

11. Berdasarkan kenyataan yang diperoleh selama persidangan dalam perkara ini, Hakim tidak menemukan hal-hal yang dapat melepaskan terdakwa dari pertanggungjawaban pidana, baik sebagai alasan pembenar (rechtsvaardigingsgronden) dan ataualasan pemaaf(schulduitsluitingsgronden), oleh karenanya Majelis Hakim berkesimpulan bahwa perbuatan yang dilakukan harus dipertanggungjawabkan kepadanya.

12. Berdasarkan pertimbangan Hakim bahwa Juliansyah mampu bertanggungjawab (toerekeningsvatbaarheid) maka harus dinyatakan bersalah atas tindak pidana yang didakwakan kepadanya oleh karena itu harus dijatuhi pidana.

13. Berdasarkan Undang-Undang Tindak Pidana Korupsi yang dijatuhi kepada Juliansyah pada pasal 11 Undang-Undang Nomor 20 Tahun 2001 Tentang Perubahan atas Undang-Undang Nomor 31 Tahun 1999 Tentang Pemberantasan Tindak Pidana Korupsi jo. Pasal 18 Undang-Undang Nomor 31 Tahun 1999 jo. Undang-Undang Nomor 20 Tahun 2001 Tentang Perubahan atas UndangUndang Nomor 31 Tahun 1999 Tentang Pemberantasan Tindak Pidana Korupsi jo. Pasal 55 ayat (1) ke-1 KUHPidana selain dijatuhkan pidana penjara, maka kepada Terdakwa dapat juga dijatuhkan pidana denda sebesar Rp. 50.000.000 dengan subsider pidana kurungan apabila pidana denda tersebut tidak dapat dibayar olehnya.

Setelah Majelis Hakim memberikan pertimbangan hukum melalui fakta-fakta hukum, maka selanjutnya Majelis Hakim memutuskan perkara atas nama terdakwa Juliansyah tersebut terbukti secara sah dan meyakinkan bersalah melakukan "tindak pidana korupsi secara bersama-sama" sebagaimana didakwakan dalam dakwaan kedua selanjutnya menjatuhkan pidana terhadap terdakwa oleh karena itu dengan pidana penjara selama 1 (satu) tahun dan denda sejumlah Rp. 50.000.000,00 (lima puluh ribu rupiah) dengan ketentuan apabila tidak dibayar maka diganti dengan pidana kurungan selama 1 (satu) bulan.

Berdasarkan uraian di atas, maka pertimbangan Hakim sudah tepat dan sesuai dengan ketentuan peraturan perundang-undangan, karena pegawai negeri dalam hal ini mempunyai pasal dan aturan yang lebih spesifik, yakni Pasal 11 UU No. 20 Tahun 2001 jo. Pasal 18 UU No. 20 Tahun 2001 jo. Pasal 55 ayat (1) butir 1 Undang-Undang Republik Indonesia Nomor 1 Tahun 1960 tentang Perubahan 
Kitab Undang-Undang Hukum Pidana (selanjutnya disebut UU No. 1 Tahun 1960). Melalui putusan yang dijatuhkan, maka Majelis Hakim sudah berusaha mewujudkan negara yang bebas dan bersih dari korupsi, kolusi, dan nepotisme.

\section{B. Penerapan Kebijakan Hukum terhadap Pegawai Negeri Sipil yang Melakukan Tindak Pidana Korupsi dalam Putusan PN Medan No. 73/Pid. Sus-TPK/2018/PN.Mdn}

Istilah kebijakan, berasal dari bahasa Inggris, yakni policyatau dalam bahasa Belanda politiek, dimana secara umum dapat diartikan sebagai prinsip-prinsip umum yang berfungsi untuk mengarahkan pemerintah (dalam arti luas termasuk pula aparat penegak hukum dalam mengelola, mengatur, atau menyelesaikan urusan-urusan publik, masalah-masalah masyarakat atau bidang-bidang penyusunan peraturan perundang-undangan dan pengaplikasian hukum/peraturan, dengan tujuan (umum) yang mengarah pada upaya mewujudkan kesejahteraan atau kemakmuran masyarakat (warga negara) ${ }^{20}$ Sedangkan Kebijakan hukum adalah usaha untuk mewujudkan peraturan-peraturan yang baik sesuai dengan keadaan dan situasi pada saat tertentu. ${ }^{21}$

Pasal 27 ayat (1) Undang-Undang Dasar Negara Republik Indonesia Tahun 1945 mengatur bahwa:

"Segala warga negara bersamaan kedudukannya di dalam Hukum dan Pemerintahan dan wajib menjunjung Hukum dan Pemerintahan itu dengan tidak ada kecualinya"

Berdasarkan ketentuan pasal di atas, maka setiap orang yang ada di Indonesia (warga negara Indonesia) bersamaan kedudukannya dihadapan hukum, tidak terkecuali apapun pekerjaan ataupun jabatannya. Lebih lanjut, berkenaan dengan kasus dalam penelitian ini, yakni Juliansyah sebagai Pegawai Negeri Sipil di Indonesia, juga mempunyai kedudukan yang sama dihadapan hukum. Sehingga apabila terbukti bersalah melakukan tindak pidana, maka haruslah dikenai sanksi pidana, serta harus menjalankan kebijakan hukum yang telah diputuskan oleh Majelis Hakim.

Sebagaimana uraian dalam pembahasan sebelumnya, pertimbangan Hakim dalam menjatuhkan putusan terhadap pegawai negeri sipil atas nama terdakwa Juliansyah yang melakukan tindak pidana korupsi, merupakan kebijakan hukum. Kebijakan hukum yang diambil oleh Majelis Hakim mengacu kepada sumber-sumber hukum dan Undang-Undang yang ada di Indonesia. Kebijakan hukum yang diterapkan oleh Majelis Hakim tidak membedakan status sosial, meskipun terdakwa adalah seorang pegawai negeri sipil. Pada dasarnya seorang pegawai negeri sipil haruslah mewujudkan negara yang sejahtera dengan menghindari melakukan praktik

${ }^{20}$ Barda Nawawi Arief. (2010). Bunga Rampai Kebijakan Hukum Pidana. Bandung: PT. Citra Aditya Bakti, hlm. 23-24.

${ }^{21}$ Nasrun Pasaribu, et al. (2017). Penyidikan Kasus Tindak Pidana Pencurian dengan Pemberatan di Wilayah Hukum Polsek Medan Baru. USU Law Journal, Universitas Sumatera Utara, 5(1), hlm. 32. 
korupsi di lingkungan pekerjaannya. Sanksi pidana di Indonesia dapat dikenakan melalui pidana penjara dan denda sesuai dengan Undang-Undang yang terkait dengan kasus tersebut.

Kebijakan hukum yang diterapkan dalam putusan tersebut adalah menyatakan bahwa terdakwa atas nama Juliansyah terbukti melakukan tindak pidana korupsi dan menjatuhkan pidana terhadap terdakwa oleh karena itu dengan pidana penjara selama 1 (satu) tahun dan denda sejumlah Rp. 50.000.000,00 (lima puluh juta rupiah) dengan ketentuan apabila tidak dibayar, maka diganti dengan pidana kurungan selama 1 (satu) bulan. Selanjutnya, menetapkan agar terdakwa tetap berada dalam tahanan, dan menetapkan masa penangkapan, serta penahanan yang telah dijalani oleh Terdakwa dikurangkan seluruhnya dari pidana yang dijatuhkan kepadanya. Kebijakan hukum tersebut sesuai dengan pasal pelanggaran yang dikenai kepada terdakwa yaitu meyakinkan bersalah melakukan tindak pidana "sebagai orang yang melakukan, menyuruh melakukan atau turut melakukan menerima hadiah atau janji padahal diketahui atau patut diduga, bahwa hadiah atau janji tersebut diberikan karena kekuasaan atau kewenangan yang berhubungan dengan jabatannya, atau yang menurut pikiran orang yang memberikan hadiah atau janji tersebut ada hubungan dengan jabatannya" sebagaimana diatur dan diancam pidana dalam Pasal 11 UU No. 20 Tahun 2001 jo. Pasal 18 UU No. 20 Tahun 2001 jo. Pasal 55 ayat (1) butir 1 UU No. 1 Tahun 1960.

\section{KESIMPULAN DAN SARAN}

Berdasarkan uraian hasil dan pembahasan, maka dapat ditarik kesimpulan bahwa pertimbangan Hakim didasari oleh ketentuan peraturan perundang-undangan, yakni Pasal 11 UU No. 20 Tahun 2001 jo. Pasal 18 UU No. 20 Tahun 2001 jo. Pasal 55 ayat (1) butir 1 UU No. 1 Tahun 1960. Melalui putusan yang dijatuhkan, maka Majelis Hakim sudah berusaha mewujudkan negara yang bebas dan bersih dari korupsi, kolusi, dan nepotisme. Adapun penerapan kebijakan hukum terhadap pegawai negeri sipil yang melakukan tindak pidana korupsi oleh Majelis Hakim ialah tidak membedakan status sosial, meskipun terdakwa adalah seorang pegawai negeri sipil. Kebijakan hukum tersebut sesuai dengan pasal pelanggaran yang dikenai kepada terdakwa. Diperlukan adanya sosialisasi tentang Undang-Undang tentang Tindak Pidana Korupsi kepada masyarakat, dan terutama kepada para Pegawai Negeri Sipil (PNS), serta adanya tindakan yang tegas dari Majelis Hakim yaitu dengan memaksimalkan hukuman atau sanksi, agar menjadi efek jera kepada para Pegawai Negeri Sipil (PNS) yang terbukti melakukan tindak pidana korupsi. 


\section{REFERENSI}

Barda Nawawi Arief. (2010). Bunga Rampai Kebijakan Hukum Pidana. Bandung: PT. Citra Aditya Bakti.

Budi Setiyono. (2017). Memahami Korupsi di Daerah Pasca Desentralisasi:Belajar dari Empat Studi Kasus. Politika: Jurnal Ilmu Politik, Universitas Diponegoro, 8(1), hlm. 27-62. doi: https://doi.org/10.14710/politika.8.1.2017.27-62

Danu Surya Putra \& Rehnalemken Ginting. (2018). Analisis Dasar Pertimbangan Hakim dalam Menjatuhkan Putusan Bebas Tindak Pidana Korupsi Dana Tunjangan Penghasilan Aparat Pemerintah Desa Kabupaten Tapanuli Selatan. Recidive: Jurnal Hukum Pidana dan Penanggulangan Kejahatan, Universitas Sebelas Maret, 7(2), hlm. 125-135.

Indra Kumalasari Munthe. (2018). Analisis Yuridis Tindak Pidana Korupsi yang Dilakukan oleh Aparatur Sipil Negara Ditinjau dalam UU Nomor 5 Tahun 2014 tentang Aparatur Sipil Negara. Jurnal Hukum Kaidah: Media Komunikasi dan Informasi Hukum dan Masyarakat, Universitas Islam Sumatera Utara, 17(2), hlm. 14-24.

Listiyono Santoso, Dewi Meyriswati, \& Ilham Nur Alfian. (2014). Korupsi dan Mentalitas: Kendala Kultural dalam Pemberantasan Korupsi di Indonesia. Masyarakat, Kebudayaan dan Politik, Universitas Airlangga, 27(4), hlm. 173-183. doi: http://dx.doi.org/10.20473/mkp.V27I42014.173-183

Mokhammad Najih \& Soimin Soimin. (2012). Pengantar Hukum Indonesia: Sejarah, Konsep Tata Hukum, dan Politik Hukum Indonesia. Malang: Setara Press.

Muhammad Rezza Kurniawan \& Pujiyono Pujiyono. (2018). Modus Operandi Korupsi Pengadaan Barang dan Jasa Pemerintah oleh PNS. Law Reform, Universitas Diponegoro, 14(1), hlm. 115-131. doi: https://doi.org/10.14710/lr.v14i1.20241

Nasrun Pasaribu, et al. (2017). Penyidikan Kasus Tindak Pidana Pencurian dengan Pemberatan di Wilayah Hukum Polsek Medan Baru. USU Law Journal, Universitas Sumatera Utara, 5(1), hlm. 30-40.

Nurmalita Ayuningtyas Harahap. (2018). Revitalisasi Manajemen Aparatur Sipil Negara Melalui Pemberhentian Tidak dengan Hormat bagi Pegawai Negeri Sipil yang Terlibat Tindak Pidana Korupsi. Jurnal Panorama Hukum, Universitas Kanjuruhan Malang, 3(2), hlm. 155-170. doi: https://doi.org/10.21067/jph. v3i2.2737

Peter Mahmud Marzuki. (2013). Penelitian Hukum. Jakarta: Kencana Prenada Media Group.

Putusan Pengadilan Negeri Medan Nomor 73/Pid.Sus-TPK/2018/PN.Mdn tentang Putusan Akhir Perkara Tindak Pidana Korupsi Atas Nama Juliansyah.

Reni Susanti. (2020, 29 Juli). 44 Persen Terpidana Kasus Korupsi Berasal dari PNS. Dalam Kompas.com. Diakses dari https://bandung.kompas.com/ $\mathrm{read} / 2020 / 07 / 29 / 06183511 / 44$-persen-terpidana-kasus-korupsi-berasaldari-pns?page=all, pada tanggal 3 Agustus 2020 . 
Salle Salle, La Ode Husen, \& Lauddin Marsuni. (2020). Tinjauan Hukum Mahkamah Konstitusi dalam Perkara Pengujian Undang-Undang Nomor 17 Tahun 2012 tentang Perkoperasian. Sovereign: Jurnal Ilmiah Hukum, CV. Social Politic Genius (SIGn), 2(2), hlm. 1-25. doi: https://doi.org/10.37276/sjih.v2i2.33

Sanafiah Faisal. (1995). Format-Format Penelitian Sosial: Dasar-Dasar dan Aplikasi. Jakarta: PT. Raja Grafindo Persada

Sarah Sarmila Begem, Nurul Qamar, \& Hamza Baharuddin. (2019). Sistem Hukum Penyelesaian Pelanggaran Hak Asasi Manusia (HAM) Berat Melalui Mahkamah Pidana Internasional. SIGn Jurnal Hukum, CV. Social Politic Genius (SIGn), 1(1), hlm. 1-17. doi: https://doi.org/10.37276/sjh.v1i1.28

Sulardi Sulardi \& Yohana Puspitasari Wardoyo. (2015). Kepastian Hukum, Kemanfaatan, dan Keadilan terhadap Perkara Pidana Anak: Kajian Putusan Nomor 201/Pid. Sus/2014/PN.Blt. Jurnal Yudisial, Komisi Yudisial Republik Indonesia, 8(3), hlm. 251-268.

Surat Edaran Menteri Dalam Negeri Republik Indonesia Nomor 180/6867/SJ Tahun 2018 tentang Penegakan Hukum terhadap Aparatur Sipil Negara yang Melakukan Tindak Pidana Korupsi.

Suteki Suteki \& Galang Taufani. (2018). Metodologi Penelitian Hukum: Filsafat, Teori, dan Praktik. Jakarta: PT. Raja Grafindo Persada.

Undang-Undang Dasar Negara Republik Indonesia Tahun 1945.

Undang-Undang Republik Indonesia Nomor 1 Tahun 1960 tentang Perubahan Kitab Undang-Undang Hukum Pidana. (Lembaran Negara Republik Indonesia Tahun 1960 Nomor 1. Tambahan Lembaran Negara Republik Indonesia Nomor 1921).

Undang-Undang Republik Indonesia Nomor 8 Tahun 1981 tentang Hukum Acara Pidana. (Lembaran Negara Republik Indonesia Tahun 1981 Nomor 76. Tambahan Lembaran Negara Republik Indonesia Nomor 3209).

Undang-Undang Republik Indonesia Nomor 20 Tahun 2001 tentang Perubahan Atas Undang-Undang Nomor 31 Tahun 1999 tentang Pemberantasan Tindak Pidana Korupsi. (Lembaran Negara Republik Indonesia Tahun 2001 Nomor 134. Tambahan Lembaran Negara Republik Indonesia Nomor 4150).

Naomi Sari Kristiani Harefa, et al. (2020). Dasar Pertimbangan Hakim terhadap
Tindak Pidana Korupsi yang Dilakukan oleh Pegawai Negeri Sipil (PNS): Studi Kasus
I Putusan Pengadilan Negeri Medan Nomor: 73/Pid.Sus-TPK/2018/PN.Mdn. SIGn
Jurnal Hukum, CV. Social Politic Genius (SIGn), 2(1), hlm. 30-42. doi: https://doi.
I org/10.37276/sjh.v2i1.68 